\title{
Self-Awareness and Leadership Skills of Female Students in Outdoor Camp*
}

\author{
Melike Esentaş ${ }^{1}$, Selhan Özbey ${ }^{2}$, Pınar Güzel ${ }^{2}$ \\ ${ }^{1}$ Batman University, School of Physical Education and Sports, Turkey \\ ${ }^{2}$ Manisa Celal Bayar University, Faculty of Sport Sciences, Turkey \\ Correspondence: Pınar Güzel, Manisa Celal Bayar University, Faculty of Sport Sciences, Turkey.
}

Received: August 15, 2017

doi:10.11114/jets.v5i10.2600
Online Published: September 20, 2017

URL: https://doi.org/10.11114/jets.v5i10.2600

\begin{abstract}
This study aims to determine the role of youth camp practices, organised by the Ministry of Youth and Sports, in the development of self-awareness and leadership skills of female students participating in youth camps. As a result of analysis of the data collected with triangulation method -observation, focus group discussions and document analysis-, common ten (10) kernel categories were obtained. These themes are prejudice, communication, friendships, acculturation, team work, responsibility, self-confidence, consciousness, volunteering and taking role model. Finally, it is determined that youth camp practices contribute in the development of self-awareness and leadership skills in female students according to "obtained kernel themes".
\end{abstract}

Keywords: leadership skills, outdoor camp programme manager, self-awareness, youth camps, youth camp leader

\section{Introduction}

Leadership skills; can be expressed as "direction, guidance, enlightenment, management and ability to provide impact" (Barbary, 1999). Babu, Rao, Ahmed and Gupta, (2008) defines leadership skills as essential resources, support and direction to achieve effective performance together with human resource power at all levels (Babu et al, 2008). Research conducted in recent years emphasize that leadership begins with self-awareness. A person who is aware of his own positive and negative features, is expected to be a better leader of the group he is leading. Therefore, the research in the fields of self-awareness and leadership are ever growing and increasing rapidly. Self-awareness, expresses a person's own emotions, thoughts, desires in a realistic way and the process of knowing strengths and at the same time weaknesses about its own characteristic features (Kernis, 2003).

Every individual can reach success in its own right or able to guide a group but a person who owns its self-awareness will be a better leader to others using accurate decision-making process while keeping emotions and thoughts in control. In order to lead the individuals to accomplish some certain goals and visions, there is need for a leader who possesses a leading property to rally individuals and determine their courage, desire and self-awareness.

Another method used to reveal and improve leadership capability is nature camp practices. Buller (1995), draws attention to nature camp practices in his studies and argues that outdoor practices conclude in trust development of interpersonal skills such as better communication capability, risk taking and team building and that these effects are observed as sustainable.

Emphasized by the researcher, nature camp practices and albeit in limited time, enable individuals to get information about natural processes, improves their aptitude for the nature, make them more sensitive, conscious, more independent, creative and leads to critical thinking (Ozaner, 2004).

Applied as a leisure activity, youth camps are thought to be contributing to female students' physical, cognitive and affective ways via nature camp practices in limited time. This research; aims to determine the effect youth camp practices organized by the Ministry of Youth and Sports for improving self-awareness and leadership skills of female students.

\footnotetext{
*This work was produced from a doctoral thesis.
} 


\section{Method}

\subsection{Model of the Research}

Phenomenology, a design within qualitative designs was used in this research. Within the model of this research, methods and techniques used to conclude the problems in hand in a statistical meaningful are shown in Figure 1 named Methodical Road Map.

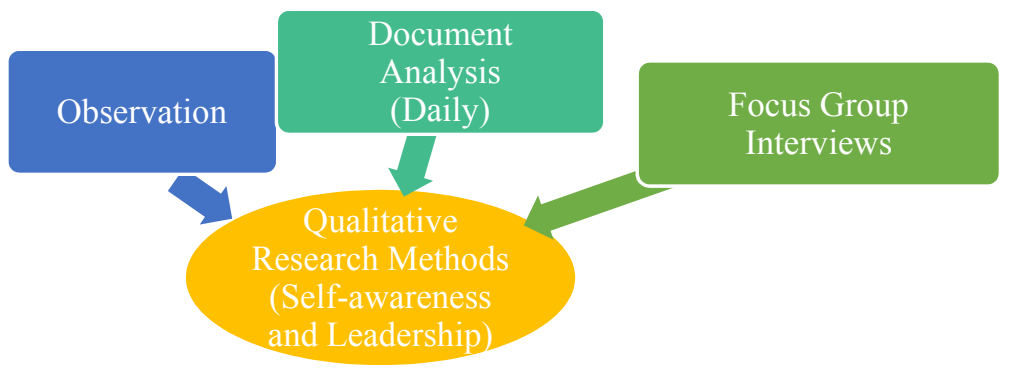

Figure 1. Methodical Road Map of Research (Source: Esentaş, Özbey \& Güzel, 2016)

\subsection{Data Collection Method}

In the research, observation, focus group discussions and document analysis (diary) methods were used within qualitative research methods. Activities applied in seven (7) days camp environment was used to thoroughly describe self-awareness and leadership skills of female students. Observation was made by the researcher and youth camp leader. This observation studies were made in natural environment where action takes place and in most cases executed by participatory observation method.

The youth camp leaders were divided into two (2) as group leaders and activity leaders. Group leaders consist successful participants of the leader training course given by The Ministry of Youth and Sports. In the research, every group consists of 18 to 22 female students. There is a group leader assigned for every group. Group leaders' missions and groups were determined by the programme camp managers. Activity leaders are experts from the fields like theatre, folk dances, handicraft, archery etc. Observers partaking in research, sex, camp title, level of education and years of experience in camps is given in details (Table 1).

Table 1. Observer Profile

\begin{tabular}{|c|c|c|c|c|c|c|}
\hline Observer & Code & $\begin{array}{l}\text { Gende } \\
\mathbf{r}\end{array}$ & Title of the camp & $\begin{array}{l}\text { Education } \\
\text { level }\end{array}$ & $\begin{array}{l}\text { Camp } \\
\text { years }\end{array}$ & Experience \\
\hline Researchers observers & $\mathrm{RO}$ & $\mathrm{F}$ & Programme manager & University & 6 & \\
\hline Observer & $\mathrm{O} 1$ & $\mathrm{~F}$ & Group leader & University & 4 & \\
\hline Observer & $\mathrm{O} 2$ & $\mathrm{~F}$ & Activity leader & University & 1 & \\
\hline Observer & $\mathrm{O} 3$ & $\mathrm{~F}$ & Group leader & University & 3 & \\
\hline Observer & $\mathrm{O} 4$ & $\mathrm{~F}$ & Group leader & University & 2 & \\
\hline Observer & $\mathrm{O} 5$ & $\mathrm{~F}$ & Group leader & University & 3 & \\
\hline Observer & O6 & $\mathrm{F}$ & Activity leader & University & 4 & \\
\hline Observer & $\mathrm{O} 7$ & $\mathrm{~F}$ & Group leader & University & 3 & \\
\hline Observer & $\mathrm{O} 8$ & $\mathrm{~F}$ & Group leader & University & 2 & \\
\hline Observer & O9 & $\mathrm{F}$ & Group leader & University & 2 & \\
\hline Observer & $\mathrm{O} 10$ & $\mathrm{~F}$ & Group leader & University & 2 & \\
\hline Observer & O11 & $\mathrm{F}$ & Group leader & University & 1 & \\
\hline Observer & $\mathrm{O} 12$ & $\mathrm{~F}$ & Group leader & University & 3 & \\
\hline Observer & O13 & $\mathrm{F}$ & Group leader & University & 4 & \\
\hline Observer & O14 & $\mathrm{F}$ & Activity leader & University & 3 & \\
\hline Observer & $\mathrm{O} 15$ & $\mathrm{~F}$ & Group leader & University & 3 & \\
\hline Observer & O16 & $\mathrm{F}$ & Group leader & University & 2 & \\
\hline Observer & $\mathrm{O} 17$ & $\mathrm{~F}$ & Activity leader & University & 2 & \\
\hline Observer & O18 & $\mathrm{F}$ & Group leader & University & 1 & \\
\hline
\end{tabular}

*Codes were used to protect the identity of the respondents

Before the focus group discussions, a pilot study was applied to evaluate possible problems for the researcher and the female students, and a reliability study was also done to determine problem sources. Ten (10) female students, having similar characteristics representing the research population, were nominated for pilot study. Clarifications of questions were tested and interview questions were finalized. After pilot study two (2) more focus group discussions were realized. Youth camp was composed of female students from different provinces. Three (3) focus group discussions were realized including one (1) pilot 
focus group discussion with the pre-nominated female students from different provinces. The discussion environment for focus group interviews were determined by the researcher, and interviews took place in a place where the students felt comfortable.

In the first day at the youth camp, one (1) female student from every group was chosen by the group leader consisting totally ten (10) female students to keep a camp diary, and voluntary participation was encouraged. Thus, female students were informed about the necessity and importance of keeping diary for documentation method, and they were asked to write their experiences, feelings, recommendations, expectations, thoughts about the events they attend and asked to note down any emotion or subjects attracts their attention. They were given an opportunity to write at any place and time during the day in the diary, and no restriction was imposed in this respect.

\subsection{Analysis of Data}

The study used the Cohen's Kappa coefficient statistics method in order to determine the consistency between two or more coders' evaluations. Tüik, (2011) defines Cohen's Kappa coefficient as a statistical measurement used to measure inter-rated agreement for qualitative (categorical) variants (Tüik, 2011). Codes that were identified as consensus and dissensus were calculated by placing Cohen Kappa formula:

$$
\boldsymbol{\kappa}=\frac{p_{0}-p_{\mathrm{e}}}{1-p_{\mathrm{e}}}
$$

In this research; coherence between coders has been found as $\mathrm{k}=80$ after reliability measurement. For this reason, calculated values shows good level of compliance between raters (Landis and Koch, 1977).

The data collected through interview were converted into plain text using a computer. Afterwards, data were encoded via Nvivo 10 for Windows program. Also, overlapping themes of encoded data were classified by 2 specialists in the field. In the analysis of qualitative data, interviewed participants was coded with alphabetical letters (A, B, P). Information about participant profile is given in Table 2.

Table 2. Participant Profile

\begin{tabular}{|c|c|c|c|c|c|}
\hline Group & Age & Previously Camp Experience & $\begin{array}{l}\text { Previously } \\
\text { Attended } \\
\text { Volunteers } \\
\text { Organization } \\
\end{array}$ & $\begin{array}{lr}\text { Referring } & \text { to } \\
\text { Join } & \text { the } \\
\text { Outdoor } & \\
\text { Camp } & \\
\end{array}$ & Licensed Athletes \\
\hline Pilot Group - P1 & 16 & - & - & Friend & Individual Sports \\
\hline Pilot Group - P2 & 17 & - & - & Own & - \\
\hline Pilot Group - P3 & 16 & - & + & Own & - \\
\hline Pilot Group - P4 & 17 & - & - & Own & - \\
\hline Pilot Group - P5 & 16 & - & - & Own & - \\
\hline Pilot Group - P6 & 17 & - & - & Own & - \\
\hline Pilot Group - P7 & 16 & - & - & Own & - \\
\hline Pilot Group - P8 & 17 & - & + & Youth Center & Team Sports \\
\hline Pilot Group - P9 & 16 & - & - & Friend & - \\
\hline Pilot Group - P10 & 17 & - & + & Family & - \\
\hline 1.Focus Group - A1 & 17 & Ministry of Youth and Sports-Sea Camp & + & Own & Individual Sports \\
\hline 1.Focus Group - A2 & 16 & Ministry of Youth and Sports -Sea Camp & + & Youth Center & - \\
\hline 1.Focus Group - A3 & 16 & - & - & Friend & - \\
\hline 1.Focus Group - A4 & 17 & - & - & Own & Team Sports \\
\hline 1.Focus Group - A5 & 17 & - & + & Youth Center & - \\
\hline 1.Focus Group - A6 & 16 & - & + & School & Individual Sports \\
\hline 1.Focus Group - A7 & 16 & - & - & Youth Center & - \\
\hline 1.Focus Group - A8 & 17 & - & - & School & - \\
\hline 1.Focus Group - A9 & 16 & - & - & Own & - \\
\hline 1.FocusGroup-A10 & 17 & - & + & School & Team Sports \\
\hline 2.Focus Group -B1 & 16 & Ministry of Youth and Sports-Sea Camp & + & Own & Team Sports \\
\hline 2.Focus Group -B2 & 16 & Ministry of Youth and Sports-Sea Camp & + & Youth Center & - \\
\hline 2.Focus Group -B3 & 17 & - & + & Own & - \\
\hline 2.Focus Group -B4 & 17 & - & - & Friend & - \\
\hline 2.Focus Group -B5 & 17 & Ministry of Youth and Sports-Sea Camp & - & Own & Team Sports \\
\hline 2.Focus Group -B6 & 16 & - & + & Own & - \\
\hline 2.Focus Group -B7 & 16 & - & - & Family & - \\
\hline 2.Focus Group -B8 & 17 & - & + & Family & - \\
\hline 2.Focus Group -B9 & 17 & Ministry of Youth and Sports -Sea Camp & + & Own & - \\
\hline 2.Focus Group-B10 & 16 & Ministry of Youth and Sports -Sea Camp & + & Own & Individual Sports \\
\hline
\end{tabular}




\subsection{Validity and Reliability}

\subsubsection{Role of the Researcher}

The researcher is a youth camp leader. After 3 years' experience as a youth camp leader, the researcher became programme responsible for 2 years, they worked as 'instructor' in youth camps for leader training programme and works as international camp director. The factors like researcher's participatory work, duration of the study within a period of eight days, living in nature away from external factors, face to face activities, collecting information in natural environment where events take place and taking photos and taking observation notes for confirmation of findings reinforced the validity of the study. This situation provided impetus and practice to the research.

Using "diversity" (triangulation) measurement with different methods like group discussions, diary writing, photo shooting, observation from different activities and environments during the study, prevent probable prejudices and misunderstanding that may arise in research (Yıldırım and Şimşek, 2011).

Sixteen (16) observers along with the researcher collected data, and three (3) focus group discussions were made including one (1) pilot study and two (2) focus group discussions, female students who conducted focus group discussions were asked to write diaries. Thus, prevented prejudices and misunderstandings that might arise were prevented by using different methods in research. Diversity measurement methods used in this study were:

* Researcher do observation as a participant and takes field note,

* Researcher do interview as a participant and takes field note,

* Group and activity leaders do observations and take field note,

* Female students write camp diaries at any time they want during the day regularly every day,

* Group leaders and activity leaders gather around at the end of every day and make small meetings about evaluation of the day,

* Recording with camera and photo shoot was used.

Diversity measurement used in the research aims to ensure the results that were going to be obtained at the end of the research evaluated from different perspectives.

\subsubsection{Ethical Clarity}

"Ethics are the rules of conduct in research" (Walliman, 2006). This is important when conducting research with humans. With a major principle for making sure that no harm is done to any participants in the research. Because of these reasons, 'ethical clearance number' was taken from the Celal Bayar University, Ethical Commision with the date of 23 October, 2014 and number of 2014-10. Also 'permission form' and 'voluntary confirmation letter' were taken from all the participants.

\section{Findings}

There were 16 year-old 15 female students (50\%) and 17 year-old 15 female students $(50 \%)$ in the research. There were 7 people $(23.3 \%)$ with each participants having camping experience. Voluntarily, 11 people $(36.7 \%)$ attended at least one organization before, 19 people (63.3\%) never attended. All female students (30 people) said they participated voluntarily to Osmaniye Aslantaş camp within the scope of the research. $50 \%$ of the female students wanted to join the Osmaniye Aslantaş camp themselves. $13.3 \%$ were directed by their friends, $16.7 \%$ were directed by youth center, $10 \%$ were directed by their family and school to go to the camp.

The findings obtained as a result of observation, focus group discussions and document analysis within Qualitative research methods about female students' self-awareness and leadership skills are presented in Model 1, 2 and 3. 


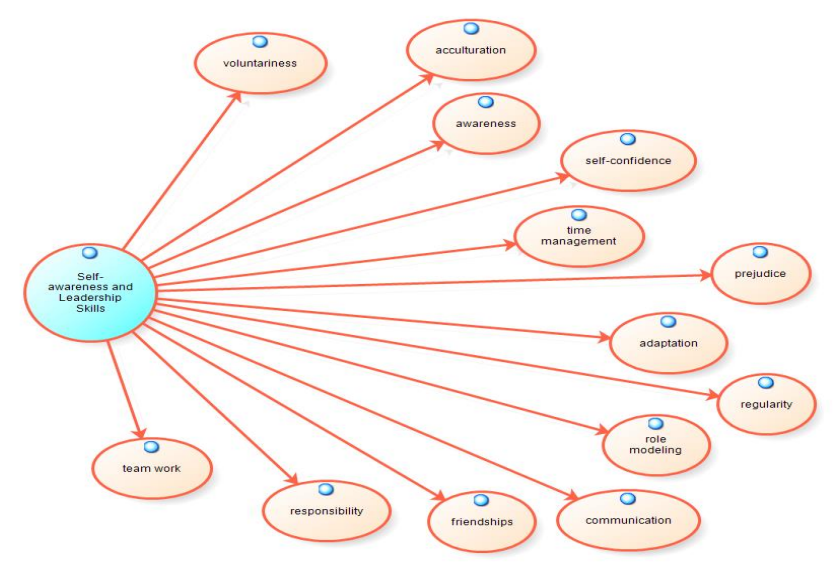

Model 1. Female students' self-awareness and leadership skills improvement

According to Model 1, observers present their opinions by themes like voluntariness, acculturation, awareness, self-confidence, time management, prejudice, adaptation, regularity, role modeling, communication, friendships, responsibility and team work.

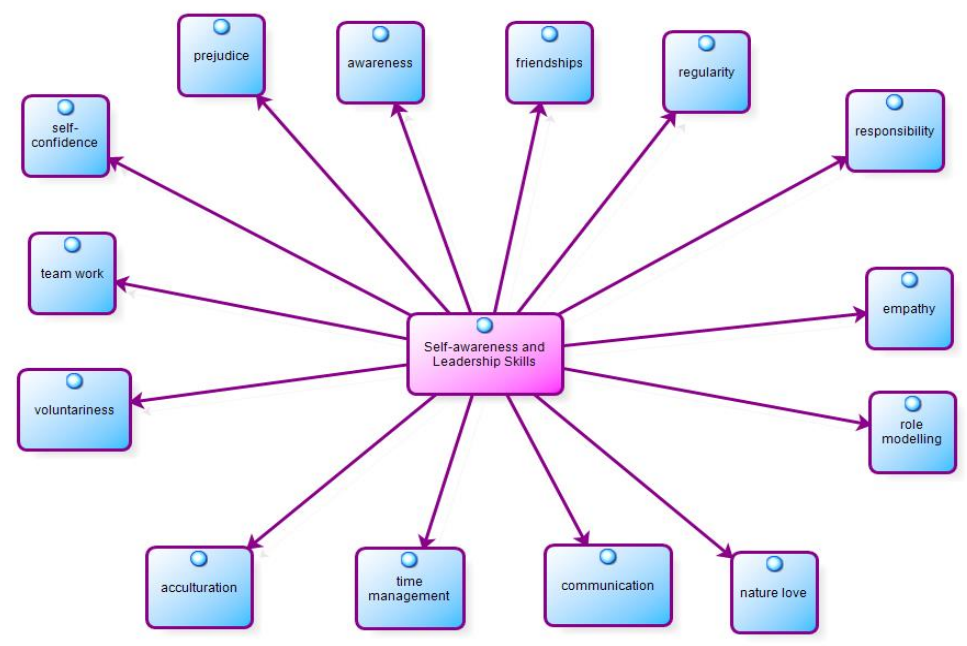

Model 2. Result of focus group discussions

According to Model 2, participants present their opinions by themes like prejudice, awareness, friendships, regularity, responsibility, empathy, role modelling, nature love, communication, time management, acculturation, voluntariness, team work and self-confidence.

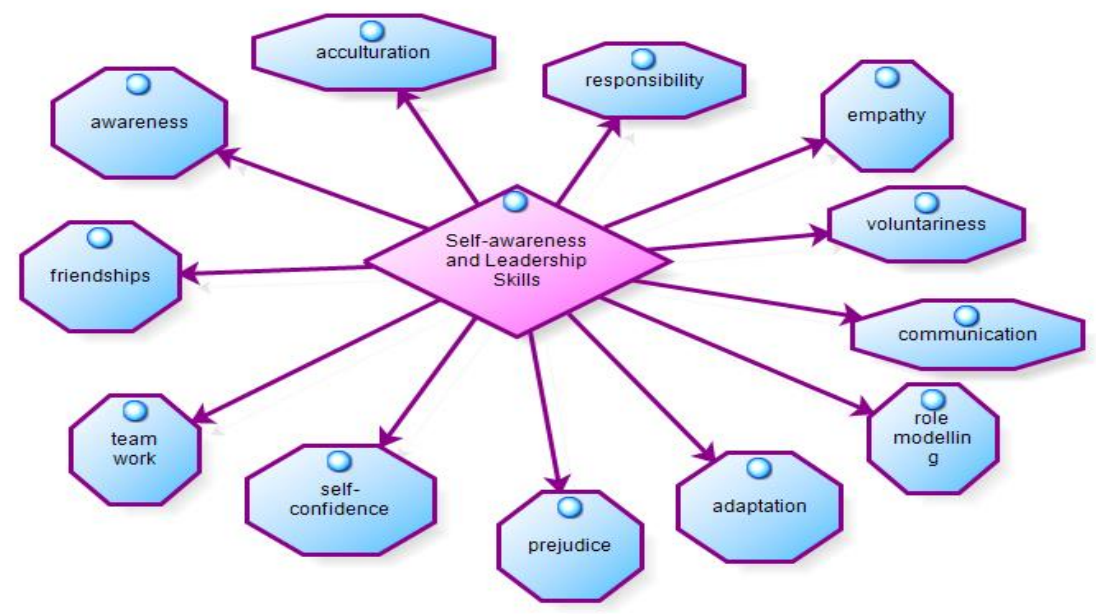

Model 3. Findings from the diaries 
According to the results obtained in Model 3, female students presented their opinions by themes like acculturation, responsibility, empathy, voluntariness, communication, role modelling, adaptation, prejudices, self-confidence, team work, friendships and awareness.

\section{Conclusions and Recommendations}

The rate of female students' participation from youth centers to the youth camps which is found as $16.7 \%$ is a remarkable finding. These institutions who are in continuous interaction with young people, considering that the membership to the youth center is a requisite, does not explain the lack of informatory activities for youth in youth centers and the weakness directing youths to camps.

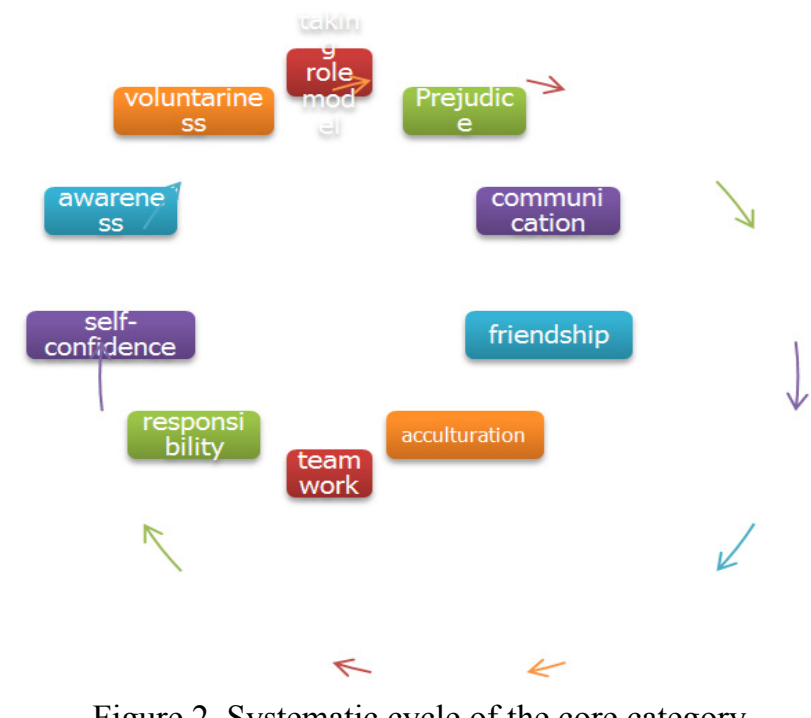

Figure 2. Systematic cycle of the core category

Themes obtained about self-awareness and leadership skills are given in Figure 1. As a result of observation, focus group discussions and camp diaries ten (10) core categories were reached. The reason why it's called 'core theme' is because it contains the essence of the ten (10) existing themes, and forms the foundation of the wholeness of the study. These themes are; prejudice, communication, friendships, acculturation, team work, responsibility, self-confidence, awareness, voluntariness and role modelling. In addition, common themes as a result of observation and focus group discussions are "regularity and time management", focus group discussions and camp diaries are "nature love and empathy", and observation and camp diaries are "adaptation".

Creswell and Miller (2000) describe triangulation as a validity procedure where researcher looks for consistences from multiple and different information sources in research for creating a theme or a category. Patton (2002) indicates that the purpose of diversification is examining the consistency and compliance of research results instead of achieving the same results from using different data sources. A total of 15 themes were obtained with triangulation. Systematic cycle of ten (10) core themes, exist in each one of them, obtained from observation, focus group discussions and document analysis (daily) shown in Figure 7. Diversity approach in the research provided consistency and harmony between study results for researcher. The most important factor in the formation of systematical core category cycle is the flow of stating thoughts and emotions from female students' focus group discussions and camp diaries. Each theme is subsidiary to each other. There is an interaction between themes. Thus emerges a cyclical system.

Prejudice: According to Kağıtçıbaşı (2010), thinking processes that affect our decisions and choices without being aware are called "mold judgement" in social and cognitive psychology. Attitudes and behaviors that emerge and take shape as a result of these stereotypes are called "prejudices". Theme observed especially in the early days is "prejudice" in nature camp process. They are expected to stay with people they don't know in the same room, and to be in a group determined by program managers. They stated that they want to return to their homes from camp in the first minutes. Whereas; from second day of the camp, it has been identified from findings that most of the things that they complain loses its importance. Female students participated in nature camp studies. The fact that female students started to overcome prejudices by spending time in activities together and by getting to know each other is indicated in the findings obtained from observation, focus group discussions and camp diaries (Model 1, 2, 3).

One of the reasons for women not to remain in the forefront of responsibilities and duties like being a leader or a manager are social and cognitive processes. Stereotypes, prejudicial attitudes and behaviors formed by cultural etiquettes are one of the most important social-cognitive factors against women leadership (Eagly, 2003; Eagly and 
Diekman, 2005; Eagly and Karau, 2002; Heilman and Eagly, 2008; Rudman and Glick, 2001; Schein, 2001; Sümer, 2006). When they started to observe and get to know each other, their stereotype thoughts decreased. Individuals who have leadership skills have to control their emotions and thoughts, and they have not to be prejudiced against people. Youth camp can help female students to have positive point of view against women leaders, and female students who want to be leader in the future can show a better performance. It can even help to go beyond the stereotypical behaviors and eliminate prejudices.

Communication: It is concluded that effective communication is a powerful factor to change prejudices and stereotypes of people from different cultures living in the same area. Also, the researcher frequently take charge in mixed camps, international camps and youth camps organized for female students by Ministry of Youth and Sports for the last six (6) years (Table 5). Although there are students from different regions and cultures in the youth camp, communication levels has been observed to increase in a positive way during camp period. In nature camps, youngsters prefer to communicate by taking a look at each other's rooms or reunite at a designated time and location instead of using phone. It can be said that youth camp practices offers a chance to form a real friendship and companionship environment, in these days virtual communication and friendship are at the most advanced level.

Friendship: Self-actualization has an important place in the socialization process. According to Büküşoğlu and Bayturan (2005), socialization is the process for young people to personalize. Young socializing takes place in relation with plenty of socializing factors like friendship, family, environmental relations, media tools, culture, art, sport and musical occupations.

First trial study about motivation of sports participation was conducted in the 1970's by Aldermen and Wood and again in the same years by Orlick. These researchers purpose is to reveal the reasons under consideration for participating in sports (transmitting Weiss and Chaumeton 1992). These first studies about motivation of sports participation revealed the most important factors are skill development and learning, entertainment, physical vitality, making friends and success (Gill et al., 1983). In this research; female students' communication powers has increased by joining social, cultural and sportive activities. It's also found out that friendly and warm behaviors of the youth camp leaders contributed to overcome the prejudices of female students and helped them learn new culture within the educational games organized by the group leaders to become friends. Making new friendships provides an environment for increase in social skills of female students and to turn it into a permanent behavior.

Acculturation: Acculturation is the most complex areas of the cross-cultural psychology. There are two means of acculturation process, as it involves multiple cultures. First of all; acculturation is the case of interaction result between two or more cultures. Secondly, encompasses at least two cultures interaction and psychological changes after that interaction (Berry, 1998). The basis of acculturation research built on the assumption that there is some cultural differences between interacting individuals and groups. When considered in terms of individuals or groups from different countries, it is predictable to have cultural differences between frequently migrating group and dominant group at the migration-receiving country. One of the most important factors in acculturation research is to reveal the presence of these cultural differences (Sam \& Berry, 2006).

In this research; female students came to youth camps from different provinces and cultures. Female students live with different cultures in camp environment and experience constant change. During the first days of camp, students from east and west regions have prejudices against each other. Female students perform regional folk dances at night entertainments through camp program. As they watch each other with the curiosity instinct awakened in them, almost all of the female students start to learn a little bit folk dances from every region. Students who have opportunity to get to know each other, observed to talk about their region, customs and traditions during trips. Thus; it can be said that youth camps contribute to female students meeting new people and discovering new cultures.

Team Work: Female students are more likely to have 'entertainment' and 'being active' than men. Also they want to participate less in risky activities (Kerr \& Vlaminkx). Apter (2001) shown that the purpose of sport for female students is discharge. 'Team member/team spirit' and 'friendship' motives are more than men in females even if they don't mean much, this is an indication of their desire to meet new people and being in a team. Physical education classes within activities not only remain limited to physical activities at school but also teaches individuals communal living and contribute to their physical, mental, emotional and social improvements (Aybek et al., 2011). In addition to this, impacton the academic success of participation in sports activities has been an important research topic in recent years (Marsh 1993).

Jergovic (2001) stated that extracurricular activities improves academic success at class, and also Managan (2002) stated that character and team work teaching at sports playgrounds has a positive effect on students success. It is believed to be a sense of belonging. It can be said that teamwork contributes to rising of behaviors like ensuring the unity and solidarity, establishing an environment of mutual trust, cooperation, interdependence, taking responsibility, sharing and empathy. 
Responsibility: İn research; female students have duties and responsibilities within program. Every day, two (2) or three (3) group were responsible for raising the camp, morning exercise, mess hall watch and evening entertainments. In this way, students take responsibilities of their friends. Also during camp period program, managers give group leaders responsibilities about encouraging, motivating etc. Group leaders also give responsibilities to female students within the group. In this way, it can be said that the best way to improve responsibility of female students for a leader is to give them responsibilities. When female students are asked to fulfil a duty, their confidence in themselves raises too. As they meet their responsibilities, they will be ready for a new responsibility. Giving positive feedback (Thanks, well done etc.) by friends and leaders along with meeting responsibility offers opportunity to strengthen female students' behaviors and also expands these behaviors into a habit. Besides, it can be said that giving students' responsibility frequently to use and enhance their skills at camp environment contributes to improvement of female students' self-awareness levels and particularly confidence in themselves.

Self-Confidence: Palmberg and Kuru (2001), after various environmental education programs (field trips, walking, camping and adventure activities) applied studies, observed that nature experiences develops students' self-confidence and makes them act more social and ethical by possessing more powerful and empathic relations with nature. In particular, it makes them more eager to join out of school activities in future. İt can be said that youth camp leaders, who gives responsibilities, values and cares sboout their opinions, encourages and motivates them to tend to their skills and knowledge, have an important role on female students' motivation.

Awareness: Emotions are more difficult to recognize than behavior. To recognize emotions; chosen emotions must be entitled, shared as far as possible, if it's not possible must be written at least. Attention should be paid to how much emotions were understood by others and having disapprovable emotions from time to time must be accepted. Experienced emotions felt by the effect of other people must be attempted to express other side (Terakye, 1995). According to Manning (1986), motives required to participate in open air recreations are 'success, loyalty, control, escape and self-awareness. Self-awareness, self-discovery, success and self-fulfillment factors are the center of person's value system and it's accepted identical to centralism element (Cater, 2006; Trauer, 2006). In youth camps, there is an opportunity to self-knowledge and self-discovery for female students. Nature camp, offers female students chance to know themselves and discover abilities that they have not found before.

Female students who found opportunity to learn by doing and living through nature camp practices, state their realization about their ability for theatre, folk dances, archery, paintball, bb gun etc. in focus group discussions and camp diaries. It is also a finding discovered by observers. During one (1) week camp period by nature camp practices, knowing oneself, acting consistently while keeping emotions and thoughts under control is important for female students' self-discoveries, especially when they are in puberty.

Voluntariness: A person who can able to offer one or some of its physical power, time, knowledge, ability and experience features to non-governmental be organizations' usual or project based jobs and doesn't have a financial gain expectation is a voluntariness. While cooperating it's also a role model to its self and environment. Interaction between partners is provided by activities (Güzel et al., 2015). It can help originate identity and common future as well as creating and protecting relations with social bonds and trust. Voluntary activities by people who make an effort to get together as part of a common goal is a feature that can be seen in many societies (Status Report about Voluntariness in the World 2011). Volunteers take active charges in International Sports Organizations and Olympics as much as professional employees (Fernandez \& Recuena, 1999). Female students who can take responsibility and perform coordination in a team, develop leadership skills in that process. Female students participate as a volunteer in youth camps where program managers and youth camp leaders also participate as a volunteer. Learning that youth camp leaders take in charge at the time they are eligible during summer months increases desire to be a volunteer as well as providing a role model as youth camp leaders for female students.

Taking a Role Model: Female students take youth camp leaders as a model who also come to camps as a volunteer. Female students observe youth camp leader and program managers consistently during camp period. They start to imitate youth camp leaders' or program managers' appearance and behaviors whom they respect, love, pay attention and feel close to. Role model becomes an idol to female students, and they let idol leaders into their lives during camp time and after that. Making photos of leaders whom they take as a model to be their cover photos at their Facebook profiles and phones is one of the behaviors observed by observers. It can be said that leaders' attitudes and behaviors are important for values like love, respect, toleration and fairness making a lasting impact on female students' characters. At the same time, it can be said that it has an effect on making female students apply for youth camp leader training like their leaders whom they take as a role model. As a result; it is determined that youth camp practices contributes to female students' self-awareness and leadership skills positively in accordance with 'the core categories revealed'. It is suggested to plan activities according to core categories revealed when preparing programs for youth camps organized by Ministry of Youth and Sports. 


\section{References}

Apter, M. J. (2001). An introduction to Reversal Theory. In M. J. Apter (Ed.), Motivational styles in everyday life: A guide to Reversal Theory, Washington, DC: American Psychological Association. https://doi.org/10.1037/10427-001

Aybek, A., İmamoğlu, O., \& Taşmektepligil, M. Y. (2011). An assessment of the atttudes of students towards physical education lesson and extracurricular activities. Journal of Sports and Performance Researches, 2(2).

Babu, G. S., Rao, T. M., Ahmed, S., \& Gupta, K. S. (2008). Relationship between leadership capability and knowledge management: a measurement approach. Journal of information \& knowledge management, 7(2), 83-92. https://doi.org/10.1142/S0219649208001968

Barbary, A. G. (1999). A study of new jersey public school teachers: attitudes and perceptions of leadership skills associated with the principal ship. Doctoral Dissertation, Seton Hall University, 5-114.

Berry, J. W. (1998). Intercultural Relations in Plural Societies. Canadian Psychology. No: 1, 12-21.

Büküşoğlu, N., \& Bayturan, (2005). The role of leısure tıme actıvitıes on the concept related to the psycho-social development of the youth, Ege University Faculty of Medicine, Department of Child Psychiatry, Ege Medical Journal, 44(3), $173-177$.

Buller P. F., McEvory, G. L., \& Cragun, J. R. (1995). A model for developing student skills and asssessing mba programs outcomes through outdoor training" journal of management education, 19, 35.

Cater, C. (2005). Looking the Part: The Relation between Adventure Tourism and the Outdoor Fashion Industry. (Edited by Michelle Aicken). Taking Tourism to the Limits: Issue, Concepts and Managerial Perspectives (First Edition). UK: Elsevier Science Ltd. 155-165.

Creswell, J. W., \& Miller, D. L. (2000). Determining validity in qualitative inquiry. Theory into Practice, 39(3), 124-131. https://doi.org/10.1207/s15430421tip3903_2

Eagly, A. H. (2003). Few women at the top: How role incongruity produces prejudice and the glass ceiling. In Leadership and power: Identity processes in groups and organizations. edited by Daan Van Knippenberg, Michael A Hogg, 79-93. https://doi.org/10.4135/9781446216170.n7

Eagly, A. H., \& Diekman. (2005). A. B. What is the problem? Prejudice as an attitude-in-context. In J. F. Dovidio, P. Glick, \& L. A. Rudman (Eds.), On the nature of prejudice: Fifty Years After Allport Malden, MA: Blackwell. 19-35.

Eagly, A. H., \& Karau, S. J. (2002). Role congruity theory of prejudice toward female leaders. Psychological Review, 109(3), 573-598. https://doi.org/10.1037/0033-295X.109.3.573

Fernandez, A., \& Reguena, G. (1999). Volunteering versus olimpizm. volunteers global society and the Olympic movement. Papers of Symposium Held in Lausuenne, 24-26 November, 2-5

Gill, D. L., Gross, J. B., \& Huddleston, S. (1983). Participation motivation in youth sports. International Journal of Sport Psychology, 14, 1-14.

Güzel, P., Ünlü, H., Özbey, S., \& Esentaş, M. (2015). Volunteerism and international sport organisations: xvii. mediterranean games. Turkish journal of Sportand Exercise, 17(1), 84-91.

Heilman, M. E., \& Eagly, A. H. (2008). Gender stereotypes are alive, well, and busy producing workplace discrimination. Industrial and Organizational Psychology: Perspectives on Science and Practice, 1, 393-398. https://doi.org/10.1111/j.1754-9434.2008.00072.x

Jergovic, D. (2001). The impact of athletic participation on the academic achievement of American adolescents. Unpublished doctoral dissertation, Loyola University, Chicago.

Kağıtçıbaşı, Ç. (2010). Today, the entrance to the people and people \& social psychology. Evrim Publishing. 273-275.

Kernis, M. H. (2003). Toward a conceptualization of optimal self-esteem. Psychological inquiry, 14, 1-26. https://doi.org/10.1207/S15327965PLI1401_01

Kerr, J. H., \& Vlaminkx, J. (1997). Gender Differences in the Experience of Risk. Personality and Individual Differences, 22, 293-295. https://doi.org/10.1016/S0191-8869(96)00198-5

Landis, R. J., \& Koch, G. G. (1977). The measurement of observer agreement for categorical data. International Biometric Society, 33(1), 164-165. https://doi.org/10.2307/2529310

Managan, J. (2002). Reformers, Sport, Modernizers: Middle-Class Revolutionaries. London: Frank Cass. 
Marsh, H. (1993). The effects of participation in sport during the last two years of high school. Sociology of Sport Journal, 10, 8-43. https://doi.org/10.1123/ssj.10.1.18

Ozaner, F. S. (2004). What to do in what situations school outdoor environmental education in turkey? V. national ecology and environment congress. Abant Izzet Baysal University \& Biologists Association, Abant-Bolu. Proceedings (Nature and Environment), 67-98.

Palmberg, I. E., \& Kuru, J. (2001). Children and nature. ATEE 26th Annual Conference: RDC 17: Environmental Education.

Patton, M. Q. (2002). Qualitative research \& evaluation methods (3rd ed.). Thousand Oaks, CA: Sage.

Rudman, L. A., \& Glick, P. (2001). Prescriptive gender stereotypes and backlash toward agentic women. Journal of Social Issues, 57(4), 743-762. https://doi.org/10.1111/0022-4537.00239

Sam, D., \& Berry, J. W. (2006). Introduction In Sam, D. L. \& Berry, J.W (Eds.). The Cambridge Handbook of Acculturation Psychology Cambridge: Cambridge University Press, 1-10.

Schein, V. E. (2001). A global look at psychological barriers to women's progress in management. Journal of Social Issues, 57, 675-688. https://doi.org/10.1111/0022-4537.00235

State of the World 's Volunteerism Report (2011) Publication: United Nations Volunteers (UNV)

Status Report of Volunteerism in the World. Publication: United Nation Volunteers (UNV), 2011.

Sümer, H. C. (2006). Women in Management: StillWaiting to be Full Members of the Club. Sex Roles, 55, 63-72. https://doi.org/10.1007/s11199-006-9059-2

Terakye, G. (1995). Nurse-patient relationship 4.Press Ankara: Aydoğdu Ofset, 16-34.

Trauer, B. (2006). Conceptualizing special interest tourismframeworks for analysis. Tourism Management, 27, 183-200. https://doi.org/10.1016/j.tourman.2004.10.004

Walliman, N. (2006). Social research methods. Thousand Oaks, CA: Sage. ISBN: 9786611244668.148. https://doi.org/10.4135/9781849209939

Weiss, M. R., \& Chaumeton, N. (1992). Motivational Orientations in Sport. (Horn, T.S., Ed.) Advances in Sport Pychology. (2002), Champaign: Human Kinetics Publishers.

Yıldırım, A., \& Şimşek, H. (2011). Qualitative research methods in the social sciences (8. Printing). Ankara: Seçkin, 2011.

\section{Copyrights}

Copyright for this article is retained by the author(s), with first publication rights granted to the journal.

This is an open-access article distributed under the terms and conditions of the Creative Commons Attribution license which permits unrestricted use, distribution, and reproduction in any medium, provided the original work is properly cited. 